\title{
Parasitic licensing of negative polarity items
}

\author{
Jack Hoeksema
}

Received: 23 January 2004 / Accepted: 6 July 2006 /

Published online: 11 September 2007

(C) Springer Science + Business Media B.V. 2007

\begin{abstract}
This paper proposes a new treatment of parasitically licensed negative polarity items, based on the idea that indefinite negative polarity items may optionally incorporate a negative feature from their licenser, and thus acquire the necessary features to in turn license a negative polarity item. The process of negative incorporation is that of Klima (Negation in English. In J.A. Fodor and J.J. Katz (Eds.), The Structure of Language. Readings in the Philosophy of Language, Prentice Hall, Englewood Cliffs, pp. 246-323, 1964), but now viewed as a potentially covert operation and offers an alternative to den Dikken's (J. Comp. Germ. Linguist., 5:35-66, 2002) seminal account of parasitic licensing. Some advantages of the covert incorporation proposal are sketched, including two applications outside the area of polarity licensing: adverbial modification by approximative adverbs, and emphatic reduplication.
\end{abstract}

Keywords Negation $\cdot$ Parasitic licensing $\cdot$ Negative polarity items

\section{The problem of parasitic licensing}

Parasitic licensing of negative polarity items is one of the few largely unexplored areas of current research in polarity sensitivity (but see den Dikken

J. Hoeksema $(\bowtie)$

Department of Dutch Language and Culture, Faculty of Arts, University of Groningen, P.O. Box 716, 9700 AS Groningen, The Netherlands

e-mail: j.hoeksema@rug.nl 
2002, 2006 for important recent work, as well as Postal 2005). The obscurity of the topic may be compared to that of the study of parasitic gaps before the 1980 s. The first time this particular topic was discussed appears to have been during the 1971 California Summer Program in Linguistics at Santa Cruz, according to Horn (2001, p. 181), by Horn himself, John Lawler and Paul Neubauer. They dubbed it secondary triggering. However, this discussion was not published, and only occasionally a few scattered remarks appeared in the literature on this phenomenon. ${ }^{1}$

In den Dikken (2006), a principled distinction is made between parasitic licensing (which is treated as analogous, structurally, to the licensing of parasitic gaps) and secondary triggering (based on local licensing by abstract negation), a distinction which will not be adopted in the present paper. I believe that the examples discussed by den Dikken as evidence for this distinction deserve further scrutiny, in part because I do not share all of his crucial judgments, and in part because a unified account of the facts should be preferable if it is at all tenable.

The aim of this paper is to add to the empirical basis of work on this (until recently) largely neglected problem, and to simultaneously propose a general account which extends beyond parasitic licensing to areas such as adverbial modification. My data will be taken from Dutch, but hopefully the analysis extends to other languages as well (cf. footnote 1). The account builds on some work from the early days of generative research on polarity items (Klima 1964), and offers an argument for a fairly abstract treatment of parasitic licensing.

By parasitic licensing of negative polarity items, the following is meant:

- Definition: An occurrence of a negative polarity item $\mathrm{P}$ is licensed parasitically just in case there is another negative polarity item $\mathrm{A}$ in the same local configuration, and moreover, this configuration would be ungrammatical without the presence of $\mathrm{A}$.

\footnotetext{
${ }^{1}$ One of the paradigms they discussed is the following, due to Lawler (as cited in Horn 2001, p. 181):
}

(i) a. ?I doubt he's been here in weeks.

b. I doubt anybody's seen him.

c. I doubt anybody's seen him in weeks.

The not-so-good occurrence of in weeks in the complement of doubt is saved by the occurrence of the more easily triggered item anybody in (c). 
The phenomenon of parasitic licensing is exemplified in Dutch by the data in $(1-3):^{2}$

Ik hoop niet dat je nog/*meer belt.

I hope not that you still/*anymore call

'I don't hope that you are still going to call.'

(2) Ik hoop niet dat je ooit van mening verandert.

I hope not that you ever of opinion change

'I don't hope you will ever change your mind.'

Ik hoop niet dat je ooit meer van mening verandert.

I hope not that you ever anymore of opinion change

'I hope that you will never change your opinion anymore.'

${ }^{2}$ Anastasia Giannakidou (p.c.) has offered the following Greek paradigm as evidence for parasitic licensing of modern Greek pja 'anymore':

(i) Dhen mou milai pja.

not me talks more

'He doesn't talk to me anymore.'

(ii) $\quad *$ O Janis dhen ipe oti mou milai pja

the Janis not said that me talks more

'Janis didn't say that he talks to me anymore'

(iii) O Janis dhen ipe oti mou milai kanenas pja.

the Janis not said that me talks anyone more

'Janis didn't say that that anybody talks to me anymore.'

Falkenberg (2001, pp. 85-6) notes cases of parasitic licensing in German. One of his examples involves ermüden+infinitive 'to tire of +infinitive', which requires clausemate negation:

Er ermüdete nicht sie mit Beweisen seiner Zuneigung zu überschütten.

He tired not her with proofs of-his affection to shower

'He did not tire of showering her with tokens of his affection.'

?*Ich glaube nicht, dass er ermüdete sie mit Beweisen seiner Zuneigung zu überschütten.

I believe not that he tired her with proofs of-his affection to shower

'I don't believe he tired of showering her with tokens of his affection.'

Ich glaube nicht, dass er jemals ermüdete sie mit Beweisen seiner Zuneigung zu überschütten.

I believe not that he ever tired herwith proofs of-his affection to shower

'I don't believe he ever tired of showering her with tokens of his affection.'

Although examples like the above make it clear that parasitic licensing is not merely an odd feature of Dutch, but more generally available as a grammatical option, it is clear much more work is needed to find out what items may benefit from it and how it is distributed across languages. 
Example 1 shows that the Dutch adverbial item meer 'anymore' is not a longdistance NPI, but generally requires a clause-mate trigger. Example 2 shows that the temporal adverbial ooit 'ever', unlike meer, can be licensed by negation in the higher clause (even in cases where there is no so-called neg-raising reading — cf. Horn 1978 for discussion). Example 3, finally, shows the effect we are interested in: the parasitic licensing of meer in the presence of ooit.

Ooit is not the only expression to boost the acceptability of an otherwise illicit polarity item. We may note that the long-distance NPI ook maar (cf. Zwarts 1986) has a similar effect on meer, as the following sentences illustrate:

(4) Je moet niet denken dat ik je nog/*meer vertrouw.

You must not think that I you still/anymore trust

'You shouldn't think that I still trust you.'

Je moet niet denken dat ik ook maar iemand meer/nog vertrouw. ${ }^{3}$

You must not think that I even anyone anymore/still trust

'You should not think that I trust anyone anymore.'

Parasitic licensing is not restricted to long-distance contexts. We may observe similar effects in environments that are not open to all polarity items, such as questions and conditionals. As we see in (6) below, the item meer is not allowed in a (non-negative) yes/no question:

Kom je nog/*meer?

Come you still/*anymore

'Are you still going to come?'

Example 7 shows that ooit is fine in the same type of context:

Heb ik je ooit beledigd?

Have I you ever insulted

'Have I ever insulted you?'

Example 8 shows the parasitic licensing effect. The presence of ooit increases the acceptability of meer:
Zou ze ooit meer iemand vertrouwen?
Would she ever anymore anyone trust
'Would she ever trust anyone anymore?'

\footnotetext{
${ }_{3}^{3}$ Note that sentence (5) does not have a neg-raising reading. Consequently the phenomenon of parasitic licensing is independent of neg-raising.

曾 Springer
} 
Similarly, ooit is acceptable in conditional clauses, whereas meer is not. However, in combination, both may turn up:

Mijn kop eraf als hij nog/*meer komt.

My head off, if he still/*anymore comes

'I'll be damned if he is still going to come.'

Mijn kop eraf, als hij ooit succes heeft.

My head off if he ever success has

'I'll be damned if he will ever be successful.'

Mijn kop eraf, als hij ooit meer succes heeft.

My head off if he ever anymore success has

'I'll be damned if he ever will be successful anymore.'

It should be noted that the parasitically licensed occurrences of meer are not perfect for most speakers. There are alternatives involving ooit + nog or ooit + weer (= ever again) which may be preferred. However, the crucial point is that meer is better in combination with ooit than it is by itself.

The account proposed here assumes that negation is associated with a feature [Neg], which may spread to other nodes. In Klima (1964), the combination of [Neg] with various abstract indefinites leads to the spell-out of negative quantifiers such as nobody, nothing, never, and so forth, while the same indefinites are spelled out as anybody, anything, and ever in the absence of the [Neg] feature. When a single [Neg] feature is spelled out on multiple indefinites, we have the phenomenon variously referred to as negative concord (e.g., Labov 1972; Ladusaw 1992) or negative spread (den Besten 1986).

Logically, the multiple exponence of the [Neg] feature does not alter the interpretation of the sentence. In particular, it is not the case that an even number of quantifiers on negative concord constructions such as Ain't no mountain high enough yields a positive or affirmative interpretation. We will suggest the same thing for the more abstract phenomenon of [Neg] spreading that is to be witnessed in the case of parasitic licensing: the feature may spread, thereby allowing for polarity items in positions otherwise not legitimized, but it does not lead to a different interpretation. Semantically, a chain of [Neg] features created by copying must therefore be distinguished from multiple instances of negation arising separately, in order to express double negation, as in, for example, I'm not saying that I'm never going to do it, where the intent is to affirm, rather than deny, albeit in an indirect way.

The main difference between negative concord and the type of Neg-spreading involved in parasitic licensing is that the latter is not overt, but covert. This means that the $[\mathrm{Neg}]$ feature is syntactically active, but not expressed by Spell Out. I will assume, on the basis of the findings of den Dikken (2002), that Neg-spreading takes place at Surface Structure (S-structure), not LF. One may speculate that Negspreading without overt exponence of the negation feature is less than optimal, given that parasitic licensing, as a phenomenon, is quite rare in comparison to negative concord, and that judgments are sometimes less than $100 \%$ positive for cases of parasitic licensing. 
The account proposed here is rather similar to that of Postal (2005), who proposes that polarity items carry a negative element with them, which later may be discharged to a position elsewhere in the sentence. It is the negative character of the polarity item which makes it a possible trigger in secondary triggering. The main difference with Postal's proposal is that I assume that indefinite polarity items are not underlyingly negative, but may optionally receive a negative feature from the context. Of course, due to reinterpretation effects known as the Jespersen cycle, indefinite NPIs may be reinterpreted over time as negative underlyingly, but then they should not require any outside triggers anymore, and for expressions such as English any or ever, this is not, as yet, the case.

\section{A possible alternative: Richards' (1998) Principle of Minimal Compliance}

Since there is a lack of fully worked-out formal accounts of parasitic licensing of polarity items, it is tempting to borrow some of the machinery that has been put in place to address parasitic gap licensing, as well as other types of parasitic licensing. A general account of such phenomena is given in Richards (1998), where a general principle, called the Principle of Minimal Compliance, is proposed to account for parasitic licensing in a wide range of domains, including the areas of reflexivity, weak crossover, VP-ellipsis and parasitic gaps. The principle is formulated as follows:

- Principle of Minimal Compliance (henceforth PMC): For any dependency D that obeys constraint $\mathrm{C}$, any elements that are relevant for determining whether $\mathrm{D}$ obeys $\mathrm{C}$ can be ignored for the rest of the derivation for purposes of determining whether any other dependency D obeys C. (Richards 1998, p. 601)

Richards illustrates and motivates this principle, among other things, with the following weak crossover paradigm:

(12) a. *Whoi did hisi mother introduce $t_{i}$ to Mary?

b. Who $\mathrm{i}$ did John introduce $\mathrm{t}_{\mathrm{i}}$ to his $\mathrm{i}$ teacher?

c. Who $_{\mathrm{i}}$ did hisi mother introduce $\mathrm{t}_{\mathrm{i}}$ to his $\mathrm{i}$ teacher?

Example 12a is a typical crossover violation. This sentence does not obey the Weak Crossover Constraint, which Richards formulates thus:

- Weak Crossover: All pronouns bound by a wh-phrase must also be bound by a trace of that wh-phrase in an A-position. (Richards 1998, p. 603)

Note that (12b), which is grammatical, does not violate this constraint, since the trace is in a higher position than the pronoun, which allows it to c-command the pronoun. Example 12c, on the other hand, does violate the constraint, yet it is better than (12a). The PMC is invoked to explain this difference. Since the second occurrence of his in (12c) is licit (cf. 12b), the wh-element who may now, by virtue of the PMC, be ignored for the purpose of computing whether the first occurrence of his complies with the Weak Crossover Constraint. 
Another illustration of the workings of the PMC is provided by the following parasitic gap paradigm, originally proposed as motivation for the theory of connectedness in Kayne (1983):

(13) a. *a person whoi people that talk to $\mathrm{e}_{\mathrm{i}}$ usually like him

b. a person whoi people that talk to John usually like $e_{i}$

c. a person who $i_{i}$ people that talk to $e_{i}$ usually like $e_{i}$

Richards (1998, p. 608) derives the connectedness effects from Huang's (1982) Condition on Extraction Domains (CED), in tandem with the PMC. The CED is formulated as follows:

- Condition on Extraction Domains: Certain empty categories (including wh-traces) must have a binder that is not separated from them by any ungoverned XP boundaries. (Richards 1998, p. 608)

Note that (13a) violates this condition since the trace is inside a relative clause (that talk to $t$ ), an ungoverned XP, while the binder is outside that relative clause. Example 13b, on the other hand, complies with the CED. Now the crucial example is $(13 \mathrm{c})$. Here there is a violation of the CED, the same in fact as in (13a), but also a gap that complies with the CED. The dependency between the CED-compliant gap and its binder is what allows us to ignore, thanks to the PMC, the CED-violation in the other dependency.

It should be noted that the PMC does not make any direct predictions about anything, including the possibility of parasitic licensing of negative polarity items. However, in conjunction with specific constraints, it may, though this will depend entirely on the formulation of the constraint. Consider for example a constraint which says that the chain A-B from licenser to polarity item must contain a long-distance item as its foot B if it contains a CP-node in between $\mathrm{A}$ and $\mathrm{B}$ :

- Long Distance Condition: If a chain A-B contains a CP-node, then B must be a long-distance item (i.e., $\mathrm{B} \in\{$ ever, any, at all, .. $\}$ )

We may apply this condition to example 3, repeated below:

Ik hoop niet dat je ooit meer van mening verandert.

I hope not that you ever anymore of opinion change

'I hope that you will never change your opinion anymore.'

First check that the dependency niet ... ooit in (3) complies with the long-distance condition. The intervening CP-node, projected by the complementizer dat, may now be ignored for the purpose of computing the acceptability of meer. (This is completely analogous to Richards' treatment of connectedness effects with parasitic gaps.)

A theory of parasitic licensing along these lines will make a number of incorrect predictions. One prediction is that deeply embedded long-distance NPIs may have a 
boosting effect on local NPIs in intermediate clauses. As example 14 shows, this is incorrect: ${ }^{4}$

(14) *Je moet niet denken dat ik meer ga vertellen dat ik ooit gekegeld heb. You must not think that I anymore go tell that I ever bowled have 'You should not think that I will tell anymore that I've ever bowled.'

Moreover, it is unclear how parasitic licensing in questions and conditional clauses is to be handled. Here, we are not asked to ignore an intervening node, but an unsuitable trigger. Of course, ignoring a trigger is dangerous, since it would lead to unlicensed elements. However, we could perhaps consider conditions such as the following:

- Meer (anymore) condition: If A-B is a polarity chain, and $\mathrm{B}=$ meer, then $\mathrm{A}$ may not have the features interrogative or conditional.

A chain headed by some (abstract) question operator and footed by ever would trivially obey the condition. By the PMC, this would allow the computational system to ignore the question operator for the purposes of verifying the licensing of anymore. Note that this treatment, apart from being a tad artificial, makes many incorrect predictions. For example, sentences such as (15), where meer and ook maar are not clause-mates, are ungrammatical, yet the prediction is that they should be just as good as example 8 .

*Zou ze meer geloven dat ook maar iemand haar komt helpen?

Would she anymore believe that even anyone her comes help

'Would she believe anymore that anyone would come and help her?'

Analogous examples can be provided for conditional clauses.

Let me stress that it is difficult to criticize the PMC, because it is not a condition that can simply be tested, but a metacondition. Hence only in conjunction with specific proposals regarding polarity items does it yield any predictions. Quite possibly, there are more promising alternatives than the ones I have sketched here.

\footnotetext{
${ }^{4}$ One of the reviewers raised the question whether switching the NPIs in (14) would make a difference. The answer is: No. Sentence (14') is ungrammatical, just like (14):
}

(14) *Je moet niet denken dat ik ooit ga vertellen dat ik meer gekegeld heb. You must not think that I ever go tell that I anymore bowled have

This is of course to be expected, given that meer requires a clause-mate trigger. 


\section{Polar HEEL}

\subsection{A special kind of polarity item}

One of the few existing discussions of parasitic licensing of NPIs is to be found in a recent paper by Marcel den Dikken (2002) on the peculiar but interesting Dutch polarity item heel 'whole, entire'. Before I present his account of parasitic licensing, it will be useful to summarize den Dikken's discussion of heel. Heel is an adjective with quantificational force in prenominal position (basically, a universal quantifier with a mereological domain). In most of its uses (cf., e.g., examples 16-17 below) it is not a negative polarity item at all:

(16) Jan rookt de hele dag.

Jan smokes the whole day

'Jan smokes all day.'

Jan at de hele paling.

Jan ate the whole eel

'Jan ate the whole eel.'

However, there is also a fairly infrequent use of heel as a polarity item, usually with a mildly pejorative or derogatory connotation, illustrated by the pair in (18-19):

Ik ken die hele vent niet.

I know that whole guy not

'I don't know that guy at all.'

*Ik ken die hele vent.

I know that whole guy

Sentences such as (19) do have a literal, non-polarity sensitive reading 'I know every part of that guy' (as opposed to just part of him), which we may ignore here, since it is not relevant for the point at hand.

\subsection{Obligatory scrambling}

One of the notable properties of this NPI is the fact that it must scope over negation. Most commonly, polar heel appears to the left of negation, a property which I will dub Obligatory Scrambling for lack of a better term. However, when heel is embedded inside a PP, it may also appear to the right of 
negation, provided the PP takes wide scope (this is possible in extraposition contexts). Note that sentences like (20) and (22) are acceptable under the literal reading:

*Ik ken niet die hele vent.

I know not that whole guy

'I don't know that guy at all.'

Ik heb die hele vent nooit gezien.

I have that whole guy never seen

'I have never seen that guy at all.'

*Ik heb nooit die hele vent gezien.

I have never that whole guy seen

'I have never seen that guy at all.'

Den Dikken views the obligatory scrambling of die hele vent as evidence that this expression must appear in Spec-NegP, the specifier position of the negation projection (cf., e.g., Haegeman 1995, for more discussion). In apparent contradiction to this, den Dikken observes that extraposition (occurrence in postverbal position) is in fact grammatical, although judgments vary somewhat, when the polarity item appears within a PP (note that the extraposition of argument-DPs is not possible in modern Dutch, quite independently of anything to do with polarity licensing):

Ik wil niets te maken hebben met die hele vent.

I want nothing to do have with that whole guy

'I want nothing to do with that guy at all.'

Den Dikken maintains that the extraposed PP raises to Spec-NegP, and is not c-commanded by niets in sentences such as (23). A question which den Dikken does not solve is how the PP may engage in this position in the Spec-Head agreement which die hele vent would normally engage in with Neg. However, it is well known that PPs may sometimes behave unexpectedly with respect to c-command requirements, acting as if they are DPs, so it is possible that whatever explains that general behavior, also explains Spec-Head agreement in this particular case. Note that den Dikken's assumptions require him to treat all constituents in (23) as moved to higher positions, including the nonfinite verbs.

Haegeman's (1995, p. 142) discussion of negative concord in West Flemish, which also appeals to the notion of Spec-Head agreement in NegP, clearly treats extraposed PPs as unable to undergo negative concord. Extraposed negative 
quantifiers may give rise to double negation readings, according to Haegeman, but not to negative concord readings. Her examples are:

$$
\begin{aligned}
& \text { da Valère van niemand nie ketent en is } \\
& \text { that V. of nobody not pleased neg-is } \\
& \text { 'that V. is not pleased with anybody' (negative concord reading) } \\
& \text { dat Valère nie ketent en is van niemand } \\
& \text { that V. not pleased neg-is of nobody } \\
& \text { 'that V. is not pleased with nobody' (double negation reading only: } \\
& \text { so V. is pleased with somebody) }
\end{aligned}
$$

Unless we assume that West Flemish and standard Dutch are structurally radically different, we must conclude that den Dikken's account of (23) and Haegeman's treatment of negative concord are mutually incompatible. ${ }^{5}$ In order to avoid this problem, I will pursue a different analysis of sentences like (23).

In my view, the crucial observation is that heel in postverbal position has a reading in which it is outside the scope of negation, presumably because the PP is adjoined to a node which is structurally higher than the negative quantifier niets. ${ }^{6}$ Heel is a rare example of an NPI that requires semantic scope over negation, rather than needing to be within the scope of negation. The reason for this unusual behavior is, I want to claim, not an idiosyncratic property of heel, but stems from the fact that heel is a universal quantifier, and polarity sensitive universal quantifiers

\footnotetext{
${ }^{5}$ An anonymous reviewer notes that Haegeman's examples involve PP-extraposition from AP, whereas the PP in example (23) originates from the VP, and that this difference might possibly explain why den Dikken's Spec-Head agreement and Haegeman's do not see eye to eye here. However, it is possible to construct examples involving extraposition from AP which for me are about as good as (23), suggesting that this particular avenue is closed.
}

(i) Ik ben nooit verzot geweest op die hele vent.

I am not crazy been about that whole guy

'I have never been crazy about that guy at all.'

(ii) Ik ben nooit blij geweest met dat hele voorstel.

I am never happy been with that entire proposal

'I have never been happy with that proposal at all.'

${ }^{6}$ Compare, e.g., the possibility of binding into the VP from extraposed PP:

(i) Ik heb over haar werk gepraat met elke medewerkster.

I have about her work talked with every employee[fem]

'I talked with every female employee about her work.'

Note that such binding is not available, or highly marginal, when the PP is not extraposed:

(ii) *?Ik heb over haar werk met elke medewerkster gepraat. [*? on bound pronoun interpretation] 
John refused help (see Hoeksema and Klein, 1995, for discussion, and an argument why all help really must be viewed as taking scope over the predicate refuse). Besides heel, Dutch has negative polarity items consisting of a universal quantifier (ieder or elk) + abstract noun, for example iedere medewerking 'all cooperation' or elke blaam 'all blame' (for similar data in French, see Muller 1991). The main difference between these latter NPIs and heel is primarily that they require negative predicates such as weigeren 'refuse' or gespeend van 'devoid of' as triggers, whereas heel is also licensed by negation.

Certain other aspects of den Dikken's analysis of heel and parasitic licensing I will not discuss in this paper, because they are orthogonal to its main points, such as his important observation that the structural constraints on parasitic gaps and parasitic licensing of NPIs need to be stated at S-structure, not LF. I have every reason to believe that this observation is correct.

\subsection{Parasitic licensing of Heel}

The fact that heel must scope over negation appears to entail another important property observed by den Dikken (2002), to wit, that it is triggered only by clausemate negation. The presence of negation in a higher clause, in particular, does not normally license polarity-sensitive heel, cf.:

Ik geloof niet dat ik die hele vent ken.

I believe not that I that whole guy know

'I don't believe I know that guy at all.'

*Niemand dacht dat ik die hele vent gezien had.

Nobody thought that I that whole guy seen had

'Nobody thought that I had seen that guy at all.'

In addition, heel is not licensed in questions and conditionals:

$$
\begin{aligned}
& \text { *Heb jij die hele vent gezien? } \\
& \text { Have you that whole guy seen } \\
& \text { 'Have you seen that guy at all?' }
\end{aligned}
$$

\footnotetext{
*Het zou me verbazen als hij die hele vent gezien had. It would me surprise if he that whole guy seen had

'It would surprise me if he had seen that guy at all.'
} 
In these two respects, then, heel is similar to meer. And just like meer, polarity heel may be parasitically licensed by expressions such as ooit:

(30) Ik geloof niet dat ik die hele vent ooit gezien heb.

I believe not that I that whole guy ever seen have

'I don't believe I have ever seen that guy at all.'

(31) Niemand dacht dat ik die hele vent ooit gezien had.

Nobody thought that I that whole guy ever seen had

'Nobody thought that I had ever seen that guy at all.'

(32) Heb jij die hele vent ooit eerder gezien?

Have you that whole guy ever before seen

'Have you ever seen that guy before at all?'

Het zou me verbazen als hij die hele vent ooit gezien had. It would me surprise if he that whole guy ever seen had 'It would surprise me if he had ever seen that guy at all.'

Den Dikken notes an apparent anti-c-command requirement on parasitic licensing of polarity items: The parasitically licensed NPI heel may not be c-commanded by the long-distance NPI ooit.

(34) *Ik geloof niet dat ik ooit die hele vent gezien heb.

I believe not that I ever that whole guy seen have

'I don't believe that I have ever seen that guy at all.'

*Heb jij ooit die hele vent eerder gezien?

Have you ever that whole guy before seen

'Have you ever seen that guy before at all.'

*Het zou me verbazen als hij ooit die hele vent gezien had.

It would me surprise if he ever that whole guy seen had

'It would surprise me if he had ever seen that guy at all.'

Den Dikken compares this to the well-known anti-c-command condition on parasitic gaps (cf. Engdahl 1983), illustrated by pairs such as:

$$
\begin{aligned}
& \text { which article did you [[file } \mathrm{t}] \text { [without reading pg]]? } \\
& \text { *which article t was [[filed] [without reading pg]]? }
\end{aligned}
$$


It should be noted, however, that den Dikken's condition is not without its problems. ${ }^{7}$ We have already seen some data that appear to be incompatible with it, in particular the examples illustrating parasitic licensing of meer, cf. (3) and (8), repeated here:

Ik hoop niet dat je ooit meer van mening verandert.

I hope not that you ever anymore of opinion change

'I hope that you will never change your opinion anymore.'

Zou ze ooit meer iemand vertrouwen?

Would she ever anymore anyone trust

'Would she ever trust anyone anymore?'

If we place the parasitic trigger in a position where it does not c-command the parasitically licensed NPI, the result may in fact become ungrammatical:

*Ik hoop niet dat je meer ooit van mening verandert.

*Zou ze meer ooit iemand vertrouwen?

When you compare the meer-data and the heel-data, it turns out that the position of the parasitic polarity item with respect to the long-distance item ooit is always the same as its relative position to nooit in cases of non-parasitic licensing. Thus die hele precedes ooit in (28-31), just like it does nooit in (21), and meer follows ooit in (3) and in (8), just as it does nooit in (41):

\section{Ze zal nooit meer iemand vertrouwen. \\ She will never anymore anyone trust \\ 'She will never trust anyone anymore.'}

Pursuing this line of thought a bit further, we may also note that just as the regular trigger nooit must be a clause-mate of meer and heel, the same is true of ooit, as was shown in (13) above for meer and in (42) below for heel:

*Ik denk niet dat die hele vent geloofde dat ik hem ooit gemogen heb.

I think not that that whole guy believed that I him ever liked have

'I don't think that that guy believed at all that I have ever liked him.'

\footnotetext{
${ }^{7}$ Compare also fn. 1 for an English example violating the anti-c-command requirement. In example (i-c), the item in weeks is c-commanded by the secondary trigger anybody. In fn.2, the Greek and German examples of parasitic licensing also both violate the anti-c-command requirement. It should be noted, however, that den Dikken (2006) makes a distinction between parasitic licensing (subject to the anti-ccommand requirement) and secondary triggering. The examples in fn.1, and in examples (3) and (8) in the text, would be exempt from the anti-c-command condition since they involve secondary triggering, rather than pure parasitism.
} 
Let me therefore suggest that ooit and other indefinite polarity items may serve as triggers of polarity items by incorporating a negative feature from the context. At least for the purposes of licensing the parasitic polarity item, they behave exactly as the corresponding n-words would. This incorporation of a negative feature can be viewed as a covert version of Klima's (1964) rule of neg-incorporation: neg-incorporation but without the accompanying morpho-syntactic change into an n-word.

The idea of polarity items receiving negative force is not new in the literature, but really a standard assumption in any account of the Jespersen cycle (Jespersen 1917). One may view polarity items with negative force as the mirror images of n-words acting as polarity items without a negative force of their own, something that many accounts of negative concord have suggested as an option for at least some of the data involved (see for instance Zanuttini 1991, on Italian n-words in questions; Progovac 1994, on Serbo-Croatian n-words; Van der Wouden and Zwarts 1993, and Déprez 1997, on French; Hoeksema 1997, on Middle Dutch; and so on.)

Note that we predict, if we take the parallel with Klima's (1964) rule of negincorporation seriously, that non-indefinite polarity items do not act as parasitic licensers, because it is only indefinites which undergo neg-incorporation. ${ }^{8}$ This prediction appears to be correct. Consider the polarity-sensitive item hoeven, which corresponds to the English modal polarity item need or the German modal brauchen.

Ik denk niet dat we daar bang voor hoeven te zijn.

I think not that we there afraid for need to be

'I don't think we need to be afraid of that.'

*Ik denk niet dat we voor die hele vent bang hoeven te zijn. ${ }^{9}$

I think not that we for that whole guy afraid need to be

'I don't think we need to be afraid of that guy at all.'

Example 44 shows that hoeven, unlike ooit, does not give rise to the parasitic licensing of NPI-heel, even though the anti-c-command requirement is met.

\section{Approximating adverbs}

Additional support for the hypothesis of covert incorporation of neg-feature is provided by some puzzling facts regarding so-called approximating adverbials such

\footnotetext{
${ }^{8}$ Of course, when there is evidence that other polarity items incorporate negation, we may expect them to act as triggers as well. The item hoeven in Dutch is, however, clearly not an expression which incorporates negation, since it always requires some form of overt negation. Den Dikken (2002) provides examples of polar heel functioning as parasitic licenser of another occurrence of polar heel. Since polar heel is part of a' definite, not an indefinite, DP, these data are potential counterexamples to the present prediction. However, the relevant judgments are exceedingly subtle.

${ }^{9}$ Den Dikken (2006) presents examples similar to (44) as fully grammatical. However, the 5 native speakers I consulted on this point all disagreed with den Dikken and rejected such examples.
} 
as almost, nearly, and so forth. Ever since Horn (1972), the possibility of adding modifiers of this type has been viewed as a test for distinguishing true polarity items on the one hand from negative and universal quantifiers, as well as free choice items, on the other. The basic facts are illustrated in (45):

(45) a. Almost nobody left.

b. Almost anybody can read and write.

c. Almost every student yawned.

d. *Almost a student yawned.

e. *Did you meet almost anybody?

f. *If you have almost ever been there, let me know.

g. *Did you see her almost anywhere?

Indefinites, including polarity items, appear to be incompatible with adverbials of the almost-class. And this is no doubt a semantic fact, since all languages have data similar to English in this regard. Yet there are problems (Muller 1991; de Swart and Sag 2002):

Je n'ai plus trouvé presque rien ridicule.

I neg-have longer found almost nothing ridiculous

'Almost nothing I found ridiculous any longer.'

If the occurrence of rien in (46) is treated as a polarity item, the use of presque is unexpected. De Swart and Sag (2002) propose that presque rien receives wide scope, and acts as a negative quantifier. This kind of example is by no means restricted to French. I have found some equally problematic data in Dutch (cf. Hoeksema 2001). The following example is one of several collected from written texts:

Ik herlas ze, en het wonderlijke was,

I reread them and the strange was

dat wat mij toen volstrekt onbegrijpelijk was geweest,

that what me then completely incomprehensible was been,

nu zonder dat ik er vrijwel iets aan hoefde veranderen, precies

now without that I there almost anything to need change, exactly

aansloot op wat ik aan het schrijven was.

fitted with what I at the writing was

'I reread them, and the strange thing was, that what had appeared completely incomprehensible to me back then, now exactly fitted what I was writing, without me having to change almost anything.'

What makes these examples truly interesting is the fact that they involve regular positive indefinite pronouns, and not n-words as in the French example, making a treatment along the lines of de Swart and Sag (2002) impossible to maintain, at first blush. At the very least, it is clear that giving these pronouns wide scope is not going 
to solve the problem. In a fairly large corpus of Dutch equivalents of almost, I counted the following combinations:

$$
\begin{aligned}
& \text { Corpus data on Dutch counterparts to almost: bijna, vrijwel, haast, nagen } \\
& \text { bijkans: } \\
& \text { Collected sentences: } 3315 \\
& \text { 'almost' + universal quantifier/determiner: } 611 \\
& \text { 'almost' + negative quantifier/determiner: } 457 \\
& \text { 'almost' + positive indefinite: } 7 \text { (iets 'something/anything' 2, iemand } \\
& \quad \text { 'someone/ anyone' 2, enig 'some, any' 2, ooit 'ever' 1) }
\end{aligned}
$$

[Other: adjectives, adverbs, and verbs]

It was especially striking that all 7 combinations with positive indefinites occur within the scope of a negative operator such as without. Note that zonder-clauses are scope islands. Quantificational material inside these clauses never takes scope over zonder, cf.:

$$
\text { Hij vertrok zonder iets te zeggen. }
$$

He left without something to say

'He left without saying anything.'

[Impossible interpretation: There is something that he left without saying.]

Hij vertrok zonder iedereen een hand te geven.

He left without everybody a hand to give

'He left without shaking hands with everybody.'

[Impossible reading: For every $\mathrm{x}$, he left without shaking hands with $\mathrm{x}$ ]

Hence giving wide scope to the indefinites is not an option. Moreover, even if wide scope were given, the problem remains that 'almost' combines with an expression of the wrong semantic class, and no explanation would be given for the fact that the indefinites must be within the scope of a negative operator. On the present account, it is assumed that positive indefinites may occasionally borrow a negative feature from their context, and so give rise to a negative universal quantifier which may combine with an approximative adverb. I should stress the word occasionally here. The phenomenon appears to be rare, to judge from the small numbers of cases listed in (48) (about 7 per 1000 if we restrict our attention to cases with quantifiers and determiners only), and from the equally small numbers of parasitically triggered NPIs. The fact that it is rare should however not be interpreted as implying that neg-incorporation is grammatically marginal, in the sense of only yielding sentences that are barely acceptable.

\section{Emphatic reduplication in Dutch}

Just like the previous section, this one provides independent evidence for the hypothesis that Neg-features may incorporate in a covert fashion, this time from a 
special construction. Dutch, like German, has a rhetorical device which I will call emphatic reduplication, and which involves the coordination of two copies of the same expression by means of the complex coordinator string maar dan ook:

$$
\begin{aligned}
& \text { Nooit maar dan ook nooit weer! } \\
& \text { Never but then also never again } \\
& \text { 'Never, absolutely never again!' }
\end{aligned}
$$

Het was erg, maar dan ook erg koud.

It was very but then also very cold

'It was very, very cold.'

A German counterpart to the above sentences is:

Ich habe keine, aber auch keine Zeit.

I have no but also no time

'I have no, absolutely no time.'

The elements which may be reduplicated in this fashion belong to two main classes:

- universal (including negative universal) quantifiers, as in (51), and

- degree adverbs, as in (52).

It is not possible to reduplicate positive occurrences of positive indefinites:

$$
\begin{aligned}
& \text { *Er is iets, maar dan ook iets aan de hand. } \\
& \text { There is something but then also something to the hand } \\
& \text { 'There is something but then also something the matter.' }
\end{aligned}
$$

However, in a corpus study of the phenomenon (Hoeksema 2001), it was found that negative occurrences of positive quantifiers form a small set of exceptions to the claim that positive indefinites do not reduplicate:

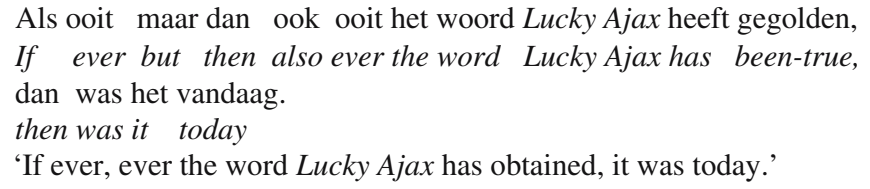

\footnotetext{
Hun argumenten hebben noch met taalkunde, noch met gezond verstand Their arguments have neither with linguistics nor with common sense iets, maar dan ook iets te maken.

anything, but then also anything to do

'Their arguments have nothing whatsoever to do with linguistics or common sense.'
}

Again, the argument can be made that this is directly accounted for by the negincorporation theory, since that would predict the possibility of positive indefinites acting as their negative counterparts vis-à-vis emphatic reduplication. Moreover, since we have seen that covert neg-incorporation is an infrequent phenomenon, we 
also predict this type of reduplication to be relatively rare, and this prediction is confirmed by the corpus data presented below: ${ }^{10}$

\author{
Corpus data \\ Collected sentences with emphatic reduplication: 815 , of which: \\ Universal quantifiers/determiners: 124 \\ Negative quantifiers/determiners: 391 \\ Indefinites under negation: 7 (2x iemand 'someone/anyone', 2x iets \\ 'something/anything, 3x ooit 'ever') \\ [Other (adverbs of degree): 293]
}

\title{
6 Summary and conclusions
}

Parasitic Licensing of negative polarity items is argued to be the result of a process of covert neg-incorporation that provides an additional local trigger. This process is optional and quite infrequent, to judge from the general paucity of parasitically licensed NPIs in corpora. Independent motivation for the existence of a process of covert neg-incorporation was adduced from modification and reduplication of indefinites in negative environments. ${ }^{11}$ An important prediction of the present account, one that definitely needs to be tested, is that parasitic licensing always involves the presence of an indefinite expression which acts as the trigger of the parasitically licensed NPI.

Acknowledgements I am indebted to three anonymous reviewers, as well as Marcel den Dikken and Anastasia Giannakidou and the audience at the workshop on negative polarity and scalarity (Potsdam, January 23, 2003) for their very useful comments on a previous draft or presentation of this paper.

\section{References}

de Swart, H. \& Sag, I. A. (2002). Negation and Negative Concord in Romance. Linguistics and Philosophy, 25, 373-417.

den Besten, H. (1986). Double negation and the genesis of Afrikaans. In P. Muysken \& N. Smith (Eds.) Substrata versus universals in Creole languages. Papers from the Amsterdam Creole workshop, April 1985 (pp. 185-230). Amsterdam: John Benjamins.

den Dikken, M. (2002). Direct and indirect polarity item licensing. Journal of Comparative Germanic Linguistics, 5, 35-66.

\footnotetext{
${ }^{10}$ The data set reported on here is slightly larger than the set reported on in Hoeksema (2001).

${ }^{11}$ Den Dikken and Giannakidou (2002, p. 53, fn. 25) cite R. Kayne (p.c.) and Postal (2000) as suggesting that sentences such as (i) below are marginally acceptable in English:

(i) ?I don't think that any linguists would I invite to the party.

Den Dikken (p.c.) suggests that such examples might be interpreted as evidence for covert negincorporation in English, in view of the fact that the inversion in the embedded clause is otherwise only found with negative quantifiers (cf. Klima 1964).
} 
den Dikken, M. (2006). Parasitism, secondary triggering and depth of embedding. In R. Zanuttini, H. Campos, E. Herburger, \& P. H. Portner (Eds.), Crosslinguistic Research in Syntax and Semantics: Negation, Tense, and Clausal Architecture. Georgetown University Press, Washington, D.C.

den Dikken, M., \& Giannakidou, A. (2002). From Hell to Polarity: ‘Aggressively Non-D-Linked' WhPhrases as Polarity Items. Linguistic Inquiry, 33, 31-61.

Déprez, V. (1997). Two types of Negative Concord. Probus, 9, 103-142.

Engdahl, E. (1983). Parasitic Gaps. Linguistics and Philosophy, 6, 5-34.

Falkenberg, G. (2001) Lexical Sensitivity in Negative Polarity Verbs. In J. Hoeksema, H. Rullmann, V. Sánchez-Valencia, \& T. van der Wouden (Eds.), Perspectives on Negation and Polarity Items (pp. 7997). Amsterdam/Philadelphia: John Benjamins.

Giannakidou, A. (2000). Negative concord? Natural Language and Linguistic Theory, 18, 457-523.

Haegeman, L. (1995). The Syntax of Negation. Cambridge: Cambridge University Press .

Hoeksema, J. (1997). Negation and Negative Concord in Middle Dutch. In D. Forget, P. Hirschbühler, F. Martineau, \& M.-L. Rivero (Eds.), Negation and Polarity. Syntax and Semantics (pp. 139-156). Amsterdam/ Philadelphia: John Benjamins.

Hoeksema, J. (2001). X maar dan ook echt X! Emfatische reduplicerende nevenschikking. Tabu, 31, 119-140.

Hoeksema, J., \& Klein, H. (1995). Negative Predicates and Their Arguments. Linguistic Analysis, 25, 146-180.

Horn, L. R. (1972). On the Semantic Properties of Logical Operators in English. Doctoral dissertation, University of California at Los Angeles.

Horn, L. R. (1978). Remarks on Neg-Raising. In P. Cole (Ed.), Pragmatics (pp. 129-220). New York: Academic.

Horn, L. R. (2001). Flaubert Triggers, Squatitive Negation, and Other Quirks of Grammar. In J. Hoeksema, H. Rullmann, V. Sánchez-Valencia, \& T. van der Wouden (Eds.), Perspectives on Negation and Polarity Items (pp. 173-200). Amsterdam/Philadelphia: John Benjamins.

Huang, J. (1982). Logical Relations in Chinese and the theory of grammar. Doctoral dissertation, Massachusetts Institute of Technology, Cambridge, MA.

Israel, M. (1996). Polarity Sensitivity as Lexical Semantics. Linguistics and Philosophy, 19, 619-666.

Israel, M. (1998). The Rhetoric of Grammar: Scalar Reasoning and Polarity Sensitivity. Doctoral dissertation, University of California at San Diego.

Jespersen, O. (1917). Negation in English and other languages. Copenhagen: A.F. Høst.

Kayne, R. S. (1983). Connectedness. Linguistic Inquiry, 14, 223-250.

Klima, E. (1964). Negation in English. In J.A. Fodor \& J.J. Katz (Eds.), The Structure of Language. Readings in the Philosophy of Language (pp. 246-323). Englewood Cliffs: Prentice Hall.

Labov, W. (1972). Negative Attraction and Negative Concord in English Grammar. Language, 48, 773-818.

Ladusaw, W. A. (1992). Expressing negation. In S. Moore \& A. Zachary Wyner (Eds.), SALT II. Proceedings of the second conference on semantics and linguistic theory (pp. 237-259). Columbus: The Ohio State University.

Landman, F. \& Kadmon, N. (1993). Any. Linguistics and Philosophy, 16, 353-422.

Muller, C. (1991). La négation en français. Geneva: Droz.

Postal, P. M. (2000). A Remark on English Double Negatives. Ms., New York University.

Postal, P. M. (2005). Suppose (if only for an hour) that negative polarity items are negation-containing phrases. Ms., New York University.

Progovac, L. (1994). Positive and Negative Polarity: A Binding Approach. Cambridge: Cambridge University Press.

Richards, N. (1998). The Principle of Minimal Compliance. Linguistic Inquiry, 29, 599-629.

van der Wouden, T. \& F. Zwarts (1993). A semantic treatment of negative concord. In U. Lahiri \& A. Z. Wyner (Eds.) Proceedings of SALT III (pp. 202-219). Ithaca: Cornell Linguistics Circle.

Zanuttini, R. (1991). Syntactic Properties of Sentential Negation: A Comparative Study of Romance languages. Doctoral dissertation, University of Pennsylvania.

Zwarts, F. (1986). Categoriale Grammatica en Algebraïsche Semantiek. Doctoral dissertation, University of Groningen. 